Facundo Martín, Gabriela Merlinsky and Catalina Toro Pérez

\title{
Héctor Alimonda, the American task of political ecology
}

Alternautas is a peer reviewed academic journal that publishes content related to Latin American Critical Development Thinking.

It intends to serve as a platform for testing, circulating, and debating new ideas and reflections on these topics, expanding beyond the geographical, cultural and linguistic boundaries of Latin America - Abya Yala. We hope to contribute to connecting ideas, and to provide a space for intellectual exchange and discussion for a nascent academic community of scholars, devoted to counter-balancing mainstream understandings of development.

How to cite:

Martín, F. Merlinsky, G. and Toro Pérez, C. (2019), Héctor Alimonda, the American task of political ecology, Alternautas, 6(1), 79-83. URL :

http://www.alternautas.net/blog/2019/5/14/hctor-alimonda-the-americantask-of-political-ecology

Editor : Alternautas

http://www.alternautas.net

London, UK.

ISSN - 2057-4924 
FaCundo Martín, Gabriela Merlinsky and Catalina Toro PÉReZ

\section{Héctor Alimonda, the American task of political ecology ${ }^{1}$}

This text is an introduction of Alternautas' mini-dossier in tribute to the work of Hector Alimonda (1947-2017). Here, Facundo Martin, Gabriela Merlinsky and Catalina Toro Pérez present Alimonda's unique contribution to the field of political ecology in Latin America. It is followed by the newly translated "In the key of south: Latin American political ecology and critical thinking", the introduction of Alimonda's latest book, Ecología Política Latinoamericana - Volumen 1 (2017), co-edited by Facundo Martín and Catalina Toro Pérez. In the next weeks, we will also publish a translation of "The coloniality of nature", an article that appeared originally in La naturaleza colonizada (2011).

Héctor Alimonda was born in Bahía Blanca, a coastal city in Argentine Patagonia. When he was young, he moved to Buenos Aires to study Sociology at the University of Buenos Aires. However, he never lost his ties to his birth place, an aspect that awakened his early passion for environmental history. His works on the so-called Desert Campaign, a military expedition in the late 19th century that constituted one of the largest indigenous genocides of the Southern Cone, are memorable. Those who know him have often heard him critiquing economic history in that, by privileging the history of successes, it hides spatial segregations leaving aside the processes of resource expropriation and the dispossession of territories and cultures.

Already having graduated as a sociologist, he travelled to Chile to pursue a master's degree in the Latin American Faculty of Social Sciences (FLACSO). However, he

1 This text was originally published at: http://www.alternautas.net/blog/2019/5/14/hctoralimonda-the-american-task-of-political-ecology on May 14th 2019. 
could not carry out the project, which was interrupted by the 1973 military coup, a circumstance that forced him to return to Argentina. Several years later, following the fateful destiny of so many Latin-American intellectuals, he had to migrate to Brazil, expelled this time by the military coup that took place in Argentina in 1976.

In Brazil, he joined the University of Sao Paulo, USP, and obtained a PhD in Human Sciences with a mention in Political Science. In his thesis, he led a comparative analysis of the political economy of the Argentinian and Brazilian oligarchic State from the late 19th century to the end of the 1930s. All these training experiences in the heat of the political vicissitudes of the time made him a prominent Latin Americanist and a great promotor of ideas and debates in the different countries he visited.

During all these years, he was deepening his research on Marxism, not from a canonical position but seeking to process the legacies of Latin American social critical thinking. His entrance into the context of socialist ideas in the Southern Cone countries was enriched by Gramscian thinking led by a new crop of intellectuals who were working toward renewing Marxist interpretations of recent Latin American history. They aimed to oppose and recover the multiple and protean forms of national and popular resistances to the bureaucratic-authoritarian regimes. It was at this time when he published a short biography of the Peruvian José Carlos Mariátegui, an intellectual emblem of a new way of understanding Marxism, closer to our reality (considering alternative rationalities such as Latin American Indigenism) and seeking the socialization of both productive resources and political power.

In later decades, Héctor was forging his own fruitful thinking that linked the most original contributions from Latin American social sciences with thinking on the environment, history and geography. This was in order to position it in the debate of ideas around the Modernity/Coloniality project. This project is a reflection on a specific world that distances itself from the modern model of science, which is not defined as a matter of technological control, but is located in the analysis of the power relations at play in the social appropriation processes of nature. At the beginning of 
the present millennium, this thinking was nourished by the ideas of Aníbal Quijano, Arturo Escobar, Germán Palacio y Enrique Leff, among others, crystalizing in an original formulation, founding the field of Latin American political ecology. This experience was institutionalized and remains in the CLACSO Political Ecology Working Group. Since then, Héctor visited several countries, academic centers and established fruitful dialogues with organizations and social movements. Those experiences are reflected in his writings on Ecuador, Guatemala, Colombia and Panama, among others.

Many of us initially approached Héctor through his publications for the CLACSO Working Group. Among them, the now classic "Nature, Society and Utopia", published in 2002, was seminal, as the first CLACSO publication on the topic, with an impressive diversity and quality of contributions. Then, in 2006 "The torments of the topic: contributions to a Latin American political ecology" was published, in which his text "A legacy in Comala" stands out for his remarkable effort to settle accounts with the Marxist tradition. In the context of the indigenous uprising of Bagua in Peru in 2011, he published a compilation of articles called "The colonized nature: political ecology and mining in Latin America”, a set of texts of cardinal value for the work of many students and activists who have continued to recreate and construct multiple ways of approaching this problem. During the presentation of this book, Héctor made reference to the devastating processes in the Andean region, where living societies and natures received the "alluvium" of the European conquest. There, coloniality was recomposed in various ways through the logics of capital accumulation and the emergence of a new form of exploitation unprecedented in history by its scale and its cruelty: mega mining.

The analysis aims to structure the framework of Latin American Political Ecology, taking as a starting point the history of unequal development and the rupture of the society-nature metabolism on a global scale. Nonetheless, it is not an approach reduced to ecological economics since there is an analysis of the historical forces that shaped the different Latin American environments. This way, the Latin American Indigenism of Mariátegui and thinking of Martí contribute to resignifying the critique of the narratives about nature. Developed since the 18th and 19th centuries, 
the dominant vision of these narratives configures a dual world between the civilized and the wild, in which nature stands as a threatening element that has to be defeated and dominated. In critiquing them, popular culture is rescued and opened up toward a dialogue of complex relationships between nature and culture.

This great operation involves moving the origins of modernity from its cradle in Northern Europe, linked to the Protestant Reformation, the origins of capitalist accumulation, and the French Revolution, and drawing attention to the "first modernity" enacted by the expanding Iberian kingdoms and their struggles. In this way, Héctor contributed to showing (following the program of modernity/decoloniality) that America has been the first periphery of the European colonial system, the hidden side of modernity. All this implies looking critically at a) the rationality of State forms and their forms of internal colonialism; b) primitive accumulation; c) the emergence of the evangelizing mission and European superiority as articulators of the Eurocentric colonial imaginary, in itself a hegemonic sense that drives and justifies the colonial project; d) human trafficking and the related imposition of subordinating forms of the working class around mining extraction and plantation economy; e) the appropriation of the bio-agro-geo-diversity; and, f) the appropriation of ancestral knowledge by the European "knowledge society".

Hence, the critique of these narratives, which build the epistemological geopolitics of the modern world, addresses the colonial fact as a founding element of the experience of modernity. With it emerges the linear paradigm of historical evolution including notions of "progress" and "development" that have been the unique experience and heritage of the European peoples who used to evaluate the progress and evolution of the "other's" world, the tropical worlds. This mentality is called "eurocentrism" and was installed as an imagined geography over five centuries.

As Héctor taught us, Latin American Political Ecology walks and travels from universities, popular struggles, big city neighborhoods, peasant worlds and environmental assemblies. It is also an emerging community and peoples inspiring themselves and articulating the resistance against the expropriating mechanisms of large companies stubborn in the chimerical "colonial mission". 
Today we honor the lucid teacher, companion and friend. To a great human being who managed to accompany, interpret and articulate this rebellious Latin America that struggles and will keep struggling to defend life and territory. Héctor Alimonda remains present among us as the creator of a fervent field of ideas that constitutes an indispensable tool to face the ecological, political and destiny crisis of our time. 